\title{
A filosofia à venda, a douta ignorância e a aposta de Pascal
}

Philosophy for Sale, Learned Ignorance and Pascal's Wager

La philosophie en vente, la savante ignorance et le pari de Pascal

\section{Boaventura de Sousa Santos}

\section{OpenEdition \\ Journals}

\section{Edição electrónica}

URL: https://journals.openedition.org/rccs/691

DOI: $10.4000 /$ rccs.691

ISSN: 2182-7435

\section{Editora}

Centro de Estudos Sociais da Universidade de Coimbra

\section{Edição impressa}

Data de publição: 1 março 2008

Paginação: 11-43

ISSN: 0254-1106

\section{Refêrencia eletrónica}

Boaventura de Sousa Santos, «A filosofia à venda, a douta ignorância e a aposta de Pascal», Revista Crítica de Ciências Sociais [Online], 80 | 2008, publicado a 01 outubro 2012, consultado a 10 fevereiro 2023. URL: http://journals.openedition.org/rccs/691 ; DOI: https://doi.org/10.4000/rccs.691

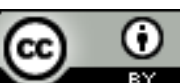

Creative Commons - Atribuição 4.0 Internacional - CC BY 4.0 https://creativecommons.org/licenses/by/4.0/ 


\title{
BOAVENTURA DE SOUSA SANTOS
}

\section{A filosofia à venda, a douta ignorância e a aposta de Pascal}

\begin{abstract}
A "epistemologia do Sul" que tenho vindo a propor visa a recuperação dos saberes e práticas dos grupos sociais que, por via do capitalismo e do colonialismo, foram histórica e sociologicamente postos na posição de serem tão só objecto ou matéria-prima dos saberes dominantes, considerados os únicos válidos. Os conceitos centrais da epistemologia do Sul são a sociologia das ausências, a sociologia das emergências, a ecologia de saberes, e a tradução intercultural. Não se trata verdadeiramente de uma epistemologia, mas antes de um conjunto de epistemologias. Ao contrário das epistemologias do Norte, as epistemologias do Sul procuram incluir o máximo das experiências de conhecimentos do mundo. Nelas cabem, assim, depois de reconfiguradas, as experiências de conhecimento do Norte. Abrem-se pontes insuspeitadas de intercomunicação, nomeadamente com as tradições ocidentais que foram marginalizadas, desacreditadas ou esquecidas pelo que no século XIX passou a vigorar como o cânone da ciência moderna.
\end{abstract}

\section{A filosofia à venda}

Suponhamos que, por terem deixado de ser úteis aos seus adeptos, eram postas à venda as filosofias e as teorias que nos acompanharam nos últimos séculos ou mesmo apenas nas últimas décadas: determinismo, livre arbítrio, universalismo, relativismo, realismo, construtivismo, marxismo, liberalismo, neoliberalismo, estruturalismo, pós-estruturalismo, modernismo, pós-modernismo, colonialismo, pós-colonialismo, etc. Suponhamos ainda que os adeptos das diferentes teorias tinham chegado à conclusão de que não só as suas próprias teorias tinham deixado de ser úteis como também todas as outras. Não estariam, pois, interessados em comprar nenhuma delas. Os potenciais compradores, supondo que os havia, seriam necessariamente gente estranha ao mundo onde as diferentes teorias tinham sido desenvolvidas, mundo a que, por comodidade, podemos chamar o mundo académico. Antes de se disporem a comprar, fariam, naturalmente, duas perguntas: qual a utilidade que esta ou aquela teoria poderá ter para mim? Qual o preço? As diferentes teorias, elas próprias ou pela voz dos seus criadores, teriam de responder 
a estas perguntas, sob pena de ficarem por vender, e tentariam responder da maneira mais apelativa e de modo a suscitar no cálculo do potencial comprador uma boa relação entre utilidade e preço. Por estarem muitas teorias à venda, por certo que a concorrência entre elas seria elevada. A dificuldade das teorias em responder às perguntas seria tanto maior quanto é certo que as teorias estão habituadas a impor a sua utilidade, não a oferecê-la, e a defini-la em termos de verdade, a qual, obviamente, não tem preço. O resultado da venda dependeria não só da bolsa dos compradores, como do valor dos préstimos que eles atribuíssem às teorias, não tendo estas qualquer possibilidade de influenciar nem a bolsa nem o valor e, portanto, as decisões.

Convenhamos que se, para todos nós, esta venda seria em si mesma um escândalo, a hierarquia de valor-preço que ela estabeleceria entre as teorias seria ainda muito maior. Mas o escândalo dos escândalos seria se os compradores afortunados, achando utilidade em teorias que consideramos antagónicas (por exemplo, determinismo e livre arbítrio), as comprassem num só lote para permitir usos complementares.

Antes que o escândalo ser vire contra mim próprio, gostaria de acrescentar duas notas. A primeira é que, se tal venda ocorresse, ela não seria inédita. Ela foi proposta aproximadamente no ano 165 da nossa era por uma personagem centrífuga da antiguidade clássica, um clássico marginal da cultura ocidental que nasceu "bárbaro" da Síria, em Samósata, junto ao rio Eufrates. Refiro-me a Luciano de Samósata e ao seu diálogo A venda de filosofias (1905: 190), em que Zeus, ajudado por Hermes, põe à venda as diferentes escolas de filosofia grega, algumas delas trazidas pelos seus fundadores: pitagóricos, Diógenes, Heraclito e Demócrito (num só lote), Sócrates, Crisipo, epicurismo, estoicismo, cepticismo peripatético. Hermes atrai os potenciais compradores, todos comerciantes, gritando alto e bom som "À venda! Uma variedade sortida de filosofias vivas! Posições de todo o tipo! Pagamento à vista ou mediante garantia!" (1905: 190). A "mercadoria" vai sendo exposta, os comerciantes vão chegando e têm o direito de interrogar cada uma das filosofias à venda, começando invariavelmente com a pergunta pela utilidade para o comprador e a sua família ou grupo. O preço é estabelecido por Zeus que, por vezes, se limita a aceitar ofertas feitas pelos comerciantes compradores. A venda tem pleno êxito e Hermes termina, ordenando às teorias que deixem de oferecer resistência e sigam com os seus compradores, ao mesmo tempo que avisa o público: "Senhores, esperamos vê-los amanhã. Estaremos oferecendo novos lotes úteis para homens comuns, artistas e comerciantes" (1905: 206). 
A segunda nota é que não estou tão certo de que esta hipotética e potencialmente escandalosa venda não esteja, de facto, já a ocorrer, sob formas muito mais subtis, mas não menos eficazes, e sem causar qualquer escândalo. Substituamos Zeus e Hermes por universidades, editoras, resenhas, revistas especializadas, congressos, jornais de divulgação cultural, catálogos, amazon.com, e os comerciantes por estudantes, colegas, público culto e solvente e o contexto da venda, das utilidades e dos preços aparecerá mais ou menos evidente. A diferença é que, estando tudo à venda e ao mesmo tempo, como num supermercado, ninguém passa pela experiência humilhante de se sentir objecto de um específico acto de compra e venda. Quando tudo acontece em geral, os detalhes não são importantes.

A vantagem do método de Luciano de Samósata em relação ao contemporâneo é que ele permite criar distância em relação às teorias, ao conhecimento constituído. Transforma-as de sujeitos em objectos, cria um campo de exterioridade em relação a elas e submete-as a testes para os quais não foram desenhadas. Não permite que se disputem entre si e antes que disputem a atenção de estranhos sobre cujas preferências não têm controlo. Sujeita-as ao caos da sociedade em que são produzidas e mostra-lhes que a verdade a que aspiram - a verdade que Luciano descreve como "esta criatura sombria, de compleição indefinida... nua e sem qualquer ornamento, furtiva à observação e sempre a desaparecer de vista" (1905: 213) - não reside na correspondência a uma realidade dada e sim na correspondência a uma realidade por dar, à utilidade em função de critérios e objectivos sociais, em sentido amplo.

Em meu entender, este distanciamento é hoje mais necessário do que nunca e deve-se a uma das características mais centrais do nosso tempo, talvez a que melhor define o seu carácter transicional. Refiro-me à discrepância entre perguntas fortes e respostas fracas. Vivemos um tempo de perguntas fortes e de respostas fracas. Ao contrário de Habermas (1990), para quem a modernidade ocidental é ainda um projecto incompleto, tenho vindo a argumentar que o nosso tempo é testemunha da crise final da hegemonia do paradigma sócio-cultural da modernidade ocidental e que, portanto, é um tempo de transição paradigmática (Santos, 1995, 2000). Os tempos de transição são, por definição, tempos de perguntas fortes e respostas fracas. As perguntas fortes dirigem-se não só às nossas opções de vida individual e colectiva, mas sobretudo às fundações que criam o horizonte de possibilidades entre as quais é possível escolher. São, portanto, questões que provocam um tipo particular de perplexidade. As respostas fracas são aquelas que procuram responder sem pôr em causa o horizonte de possibilidades, imaginando nele virtualidades para esgotar o campo das 
perguntas e das respostas possíveis ou legítimas. Mas precisamente porque o questionamento dessa virtualidade está na raiz das perguntas fortes, as respostas fracas não atenuam a perplexidade que estas suscitam, podendo, pelo contrário, aumentá-la. As perguntas e respostas podem variar de acordo com a cultura e a região do mundo. Contudo, a discrepância entre a força das questões e a fraqueza das respostas parece ser comum. Deriva da diversidade contemporânea de zonas de contacto envolvendo diferentes culturas, religiões, economias, sistemas sociais e políticos e modos de vida, resultante do que vulgarmente denominamos por globalização. ${ }^{1}$ As assimetrias de poder nestas zonas de contacto são tão vastas hoje, se não mais ainda, do que no período colonial, sendo mais numerosas e intensas. A experiência de contacto é sempre uma experiência de limites e fronteiras. Nas condições presentes, é a experiência de contacto que provoca a discrepância entre as perguntas fortes e as respostas fracas.

A especificidade da discrepância entre perguntas fortes e respostas fracas na transição paradigmática que vivemos resulta de os problemas do nosso tempo - os que suscitam as perguntas fortes - terem deixado de ser objecto de reflexão por parte do conhecimento privilegiado do nosso tempo, a ciência moderna, à medida que esta se institucionalizou e profissionalizou. $\mathrm{Na}$ sua origem, a ciência teve plenamente consciência de que os problemas mais importantes da existência lhe escapavam, por exemplo, na altura, o problema da existência de Deus, o problema do sentido da vida, o problema do modelo ou modelos de uma boa sociedade, o problema da felicidade, o problema das relações entre os homens e as outras criaturas que, não sendo humanas, partilhavam com os homens a dignidade de serem igualmente criações de Deus. Estes problemas convergiam para um outro bem mais dilemático para a ciência: o problema de a ciência não poder dar conta do fundamento da sua cientificidade, da verdade científica enquanto verdade. No mundo ocidental, estes problemas continuaram a ser do domínio da filosofia e da teologia durante os séculos XVII e XVIII. A partir do século XIX, porém, e com a crescente transformação da ciência em força produtiva do capitalismo, ocorreu uma dupla redução nesta complexa relação entre saberes. Por um lado, a hegemonia epistemológica da ciência converteu-a no único conhecimento válido e rigoroso. Com isto, os problemas dignos de reflexão passaram a ser apenas aqueles a que a ciência pudesse dar resposta. Os problemas existenciais foram assim reduzidos ao que deles pudesse ser dito cientificamente, o que implicou uma dramática reconversão conceptual e analítica. Assim se criou o que, na esteira de Ortega

${ }_{1}^{1}$ Sobre os processos de globalização, ver Santos, 2001: 31-110. 
y Gasset (1987: 39), designo como pensamento ortopédico: o constrangimento e o empobrecimento causado pela redução dos problemas a marcos analíticos e conceptuais que lhes são estranhos. Com a crescente institucionalização e profissionalização da ciência - concomitante da passagem, assinalada por Foucault, do "intelectual universal" ao "intelectual específico" a ciência passou a responder exclusivamente aos problemas postos por ela. A vastidão dos problemas existenciais que lhes subjaziam desapareceu. Mas desapareceu devido a uma outra redução que entretanto ocorreu. Como acontece, em geral, com qualquer hegemonia, a hegemonia da ciência estendeu-se para além da ciência, submetendo a filosofia, a teologia e as humanidades em geral a um processo de cientifização, um processo que ocorreu de múltiplas formas, correspondentes às múltiplas faces do positivismo, sobretudo na forma de positivismo ou empirismo lógico. Com isto, o pensamento ortopédico prolongou-se para além da ciência e, com a crescente institucionalização e profissionalização destas disciplinas, os problemas por elas tratados passaram a ser exclusivamente os problemas por elas enunciados. Em suma, respostas académicas para problemas académicos cada vez mais distantes e redutores dos problemas existenciais que estavam na sua origem, cada vez mais irrelevantes para dar conta deles.

Este vasto processo de monopolização epistemológica não ocorreu sem contradições. O sinal destas está precisamente na discrepância entre perguntas fortes e respostas fracas que caracteriza o nosso tempo. Selecciono ao acaso quatro dessas perguntas. Primeira pergunta: se há uma só humanidade, por que é tão grande a diversidade dos princípios, concepções e práticas de dignidade humana e são tão óbvias as divergências e mesmo contradições entre elas? A resposta do pensamento ortopédico consiste em reduzir essa diversidade ao universalismo abstracto dos direitos humanos. Uma resposta fraca porque nega o que afirma (o universalismo) ao afirmar o que nega (a diversidade). Se os direitos humanos são múltiplos e internamente diversos, não há nenhuma razão para crer que tal multiplicidade e diversidade se confinem às que eles propõem. Basta pensar que a diferenciação interna dos direitos humanos, longe de ser um processo sistémico auto-poiético, é o resultado de contradições e lutas sociais que, entre muitas outras manifestações, se condensam em direitos.

Segunda pergunta: existe realmente uma alternativa ao capitalismo? Depois do fracasso histórico de tantas tentativas de construção de uma sociedade não capitalista, com consequências tão trágicas, não deveríamos buscar alternativas dentro do capitalismo em vez de alternativas ao capitalismo? A perplexidade causada por esta questão reside na teoria da história que lhe está subjacente. Se tudo o que existe na história é histórico, ou seja, 
tem um princípio e um fim, porque razão deveria o capitalismo ser diferente? Mas também provém de alguns factos perturbadores. Não existirá alternativa para um mundo em que 500 dos indivíduos mais ricos detêm um rendimento semelhante ao rendimento somado dos 40 países mais pobres, com uma população de 416 milhões de pessoas (PNUD, 2005: 30) e onde a catástrofe ecológica é uma possibilidade cada vez menos remota? Devemos assumir como um facto inevitável que os problemas causados pelo capitalismo só poderão ser resolvidos por mais capitalismo, que a economia da reciprocidade não é uma alternativa credível à economia do egoísmo, e que a natureza não merece outra racionalidade que não seja a irracionalidade com que é tratada pelo capitalismo? A perplexidade causada por estas perguntas é tanto maior quanto se sabe que sem a concepção de uma sociedade alternativa e sem uma luta politicamente organizada que a possibilite, o presente, por mais violento e injusto, tende a ser despolitizado - a discussão das questões políticas dá lugar à discussão do carácter dos políticos e, como consequência, deixa de ser uma fonte de mobilização para a revolta, o inconformismo e a oposição.

A resposta fraca é dupla. Por um lado, a igualdade essencial dos homens não colide com a desigualdade circunstancial do mérito entre eles. Por outro lado, a fome e a desnutrição e as pandemias não são causadas pelo capitalismo mas, pelo contrário, pela incipiente penetração deste em muitas partes do mundo. Não resultam de falhas de mercado, mas antes do facto de o mercado não estar ainda suficientemente implantado. São duas respostas fracas, por um lado, porque qualquer cidadão comum, dotado das simples luzes da vida, sabe que, se é verdade que a desigualdade depende do mérito, não é menos verdade que o mérito depende da desigualdade. E, por outro lado, porque as mesmas luzes mostram que, com excepção das vacinas, a causa de um problema não pode ser a sua solução.

A terceira pergunta pode formular-se assim: como é possível que tudo o que foi defendido em nome da paz perpétua, de Adam Smith a Kant, Locke e Hobbes (o mercado, a democracia, o direito e o Estado) tenha produzido ou tenha sido impotente para impedir a produção da situação de guerra perpétua em que nos encontramos? A resposta fraca é também aqui dupla. As guerras entre países do Sul global são o resultado do despotismo e do atraso civilizacional, enquanto as guerras entre os países do Norte global e os do Sul global (incluindo o colonialismo) são o resultado da luta contra o despotismo, em nome da democracia e do progresso civilizacional. A resposta é fraca porque para qualquer cidadão, dotado das simples luzes da vida, é estranho que, por razões tão opostas, se produza exactamente o mesmo resultado: a morte desnecessária de milhões de pessoas inocentes. 
Se, por definição, o despotismo não se pode impor democraticamente, é possível impor despoticamente a democracia? $\mathrm{O}$ atraso civilizacional de alguns é o oposto ou a consequência do avanço civilizacional de outros? O cidadão comum tem, assim, de guardar as perguntas fortes para si.

Finalmente, a quarta pergunta. Parece evidente que, sem o que hoje designamos por natureza, a humanidade não pode sobreviver. Como explicar então que o mais ambicioso projecto, posto em marcha nos últimos quatrocentos anos, para controlar a natureza e a colocar ao serviço do homem, tenha resultado no mais trágico descontrolo e na ameaça, cada vez mais iminente, à sobrevivência da humanidade? A resposta fraca é conhecida e também é dupla: os problemas ambientais são problemas científicos e tecnológicos que se podem resolver com mais ciência e tecnologia; a criação de mercados ambientais de indústrias da ecologia (não necessariamente ecológicas) pode trazer uma nova fonte de equilíbrio e de sustentabilidade ambientais. Esta resposta deixa o cidadão comum, dotado das simples luzes da vida, com uma inquietante perplexidade. Como é que estes mercados ambientais e indústrias da ecologia podem garantir a sustentabilidade ambiental se a sustentabilidade de uns e de outras depende da contínua ameaça da insustentabilidade ambiental?

Esta discrepância entre perguntas fortes e respostas fracas é uma característica geral do nosso tempo, constitui o espírito epocal, mas os seus impactos nos países do Norte global e do Sul global são muito distintos. As respostas fracas têm alguma credibilidade no Norte global porque foi neste que mais se desenvolveu o pensamento ortopédico e porque, traduzidas em políticas, são as respostas fracas que asseguram a continuação da dominação neocolonial do Sul global pelo Norte global e permitem aos cidadãos deste último beneficiar dessa dominação sem que dela se dêem conta. No Sul global, as respostas fracas traduzem-se em imposições ideológicas e violências de toda a espécie no quotidiano dos cidadãos, excepto no das elites que constituem o pequeno mundo do Sul imperial, a "representação" do Norte global no Sul global. Adensa-se, no entanto, no espírito da época, o sentimento de que esta diferença de impactos, apesar de real e abissal, esconde a tragédia de uma condição comum: a saturação de conhecimento-lixo incessantemente produzido por um pensamento ortopédico que há muito deixou de pensar nas mulheres e nos homens comuns. Esta solidão exprime-se na carência inabarcável de conhecimento credível e prudente que nos garanta a todos, mulheres, homens e natureza, uma vida decente. ${ }^{2}$ Essa carência não

\footnotetext{
${ }^{2}$ A problemática da construção de um conhecimento prudente para uma vida decente é analisada em Santos (org.), 2003.
} 
nos permite sequer identificar e muito menos definir a verdadeira dimensão dos problemas que afligem a época. Eles manifestam-se como um conjunto de sentimentos contraditórios: exaustão que não esconde carência, mal-estar que não esconde injustiça, raiva que não exclui esperança. A exaustão decorre da incessante doutrinação de vitórias onde os cidadãos, com as simples luzes da vida, vêem derrotas, de soluções onde vêem problemas, de verdades periciais onde vêem interesses, de consensos onde vêem resignações. O mal-estar decorre da falta de razoabilidade cada vez mais patente da racionalidade proclamada pelo pensamento ortopédico, uma máquina de injustiça que se vende a si própria como máquina de felicidade. A raiva emerge da regulação social disfarçada de emancipação social, da autonomia individual usada para justificar servidões neoesclavagistas, da proclamação reiterada da impossibilidade de um outro mundo melhor, para calar a ideia difusa, mas muito genuína, de que a humanidade e a natureza têm direito a algo melhor do que o actual estado de coisas. Da exaustão aproveitam-se os mestres do pensamento ortopédico para a transformar em realização plena: o fim da história (Fukuyama, 1992). Quanto ao mal-estar e à raiva, são "tratados" com próteses farmacêuticas, com a anestesia do consumo ou, na esmagadora maioria dos casos, com a anestesia da ideologia do consumo sem possibilidade realista de consumo e, finalmente, com a vertigem da indústria do entretenimento. Nenhum destes mecanismos, porém, parece funcionar de modo a disfarçar totalmente, com a eficácia do funcionamento, a abissal disfunção que ele próprio constitui ao ser necessário e eficaz.

Este espírito epocal suscita o mesmo distanciamento em relação às teorias e às disciplinas que nos é revelado por Luciano de Samósata. As teorias e as disciplinas estão demasiado ocupadas consigo mesmas para poderem responder às questões que o nosso tempo lhes coloca. $\mathrm{O}$ distanciamento explica a predominância de epistemologias negativas e, concomitantemente, de éticas e posições políticas também negativas. As razões da rejeição do que existe ética, política e epistemologicamente são muito mais convincentes do que as que são invocadas para definir e defender alternativas. Mesmo que o desequilíbrio entre rejeição e alternativa seja comum a todos os tempos, parece ser desproporcionalmente grande no nosso tempo. Porque o horizonte das revoluções modernas colapsou ou porque o nosso tempo se indecide em ser demasiado prematuro para ser pré-revolucionário ou demasiado tardio para ser pós-revolucionário? Assumir plenamente o nosso tempo significa reconhecer essa desproporção e proceder a partir dela. Significa, por outras palavras, radicalizar a rejeição e procurar as alternativas a partir da radical incerteza destas. 
No plano epistemológico, o único de que me ocupo neste texto, a rejeição implica um certo tipo de acção directa epistemológica que consiste em ocupar as teorias e as disciplinas em desrespeito pelos seus proprietários (escolas ou correntes de pensamento, instituições) com um triplo objectivo:

1 - Mostrar que as teorias e disciplinas perdem a compostura e a serenidade quando são interpeladas por questões que não tenham formulado a si próprias, por mais simples que sejam;

2 - Identificar complementaridades e cumplicidades onde as teorias e disciplinas vêem rivalidades e contradições;

3 - Mostrar que a eficácia das teorias e disciplinas reside tanto no que mostram como no que ocultam, tanto na realidade que produzem como existente, como na realidade que produzem como não-existente.

Para realizar o primeiro objectivo será útil simular experimentações sociais em que as teorias e as disciplinas sejam postas na situação dos macacos do Rei Egípcio, contada por Luciano de Samósata noutro diálogo, Opescador:

É a história de um rei egípcio que ensinou aos seus macacos a dança da espada. As criaturas, com apurado instinto imitativo, rapidamente aprenderam e passaram a actuar na corte adornadas com trajes vermelhos e máscaras. Durante algum tempo o espectáculo foi um grande êxito. Até que um dia um engenhoso espectador trouxe consigo algumas nozes e as atirou para o palco. Num ápice, os macacos esqueceram a dança, deitaram fora a sua humanidade e voltaram à sua macaquice: ei-los rasgando os trajes e esmagando as máscaras, numa luta feroz pelas nozes. E assim ruiu o corps de ballet e a solenidade do auditório. (1905: 222)

A minha hipótese é que as teorias e disciplinas reagirão de modo não-teórico e não-disciplinar quando forem objecto de questões não previstas por elas. A manipulação ortopédica que elas exercem sobre a realidade de nada lhes servirá no momento em que forem assim questionadas. A resposta não será ortopédica. A imaginação epistemológica, filosófica e sociológica do nosso tempo exercita-se privilegiadamente identificando as questões que descompõem as teorias e disciplinas e as obrigam a confrontar-se com o impensado que habita o seu pensamento. Para realizar os dois últimos objectivos também podemos socorrer-nos de Luciano de Samósata e, metaforicamente, pôr à venda, tal como Zeus e Hermes, as diferentes teorias e disciplinas. Compreende-se que haja resistência. É fácil imaginar o desconforto que terão sentido Demócrito e Heraclito ao serem vendidos no mesmo lote. Por outro lado, as teorias e disciplinas, que se consolidaram ditando utilidades à sociedade, não compreenderão que a sua utilidade possa ser objecto 
de avaliação. Do mesmo modo, as teorias e as disciplinas que teorizaram, a favor do capitalismo, a universalidade da concorrência contra a cooperação, da compra e venda contra a dádiva, do interesse próprio contra a generosidade não aceitarão que elas próprias sejam postas à venda, e muito menos por agentes intrusos e não certificados.

Mas a rejeição das teorias e disciplinas sob a forma metafórica da compra e venda não é tão radical quanto se pensa. Afinal, se há compra e venda é porque as teorias e disciplinas têm alguma utilidade. Doutro modo, seriam simplesmente deitadas ao lixo. A radicalidade reside em avaliá-las a partir de uma racionalidade mais ampla do que a que lhes subjaz. Não se trata de fazer uma sociologia convencional das teorias e das disciplinas, pois esta será sempre refém do seu objecto sob pena de se rejeitar a si mesma. Trata-se, outrossim, de construir um modo de interpelar as teorias e as disciplinas a partir de uma racionalidade mais ampla que designo por razão cosmopolita assente nos procedimentos não convencionais da sociologia transgressiva das ausências e das emergências. Como tratei detalhadamente deste tema noutro lugar (Santos, 2006: 87-126), limito-me aqui a reiterar que a sociologia das ausências parte da ideia de que a racionalidade que subjaz ao pensamento ortopédico ocidental é uma racionalidade indolente, que não reconhece e, por isso, desperdiça muita da experiência social disponível ou possível no mundo. Muita da realidade que não existe ou é impossível é activamente produzida como não existente e impossível. Para a captar, é necessário recorrer a uma racionalidade mais ampla que revele a disponibilidade de muita experiência social declarada inexistente (a sociologia das ausências) e a possibilidade de muita experiência social emergente, declarada impossível (a sociologia das emergências).

Como referi, assumir a condição do nosso tempo consiste, não só em rejeitar o pensamento ortopédico, como também em procurar alternativas a partir da radical incerteza destas. Ou seja, a sociologia das ausências e das emergências deve assentar em procedimentos epistemológicos que credibilizem a busca de alternativas em condições de elevada incerteza. Antes de identificar esses procedimentos, passo a analisar as duas grandes incertezas que confrontam o nosso tempo e que o confrontam tanto mais quanto mais ele se liberta do pensamento ortopédico e da razão indolente.

\section{O paradoxo da finitude e da infinitude}

A primeira incerteza diz respeito à diversidade inesgotável e inabarcável das experiências de vida e de saber do mundo. Os movimentos de libertação contra o colonialismo e os novos movimentos sociais - do movimento feminista ao movimento ecológico, do movimento indígena ao movimento 
dos afrodescendentes, do movimento camponês ao movimento da teologia da libertação, do movimento urbano ao movimento LGBT - além de ampliarem o âmbito das lutas sociais, trouxeram consigo novas concepções de vida e de dignidade humana, novos universos simbólicos, novas cosmogonias, gnoseologias e até ontologias. Trouxeram também novas emoções e afectividades, novos sentimentos e paixões. Foram estes movimentos que criaram as condições para a sociologia das ausências e das emergências. Paradoxalmente, este processo, que aponta para a infinitude da experiência humana, ocorreu de par com um outro, aparentemente contraditório, que foi revelando a finitude do planeta terra, a unidade da humanidade e da natureza que a habita (a hipótese Gaia), os limites da sustentabilidade da vida na terra. O que designamos por globalização contribuiu, de maneira contraditória, para aprofundar a dúplice consciência de infinitude e de finitude.

A primeira incerteza coloca-nos, pois, perante o paradoxo da finitude e da infinitude. Como é que, num mundo finito, a diversidade da experiência humana é potencialmente infinita? Por sua vez, este paradoxo coloca-nos perante uma carência epistemológica aparentemente insuperável: o saber que nos falta para captar a inesgotável diversidade do mundo. A incerteza causada por esta carência é ainda maior se tivermos em mente que a diversidade da experiência do mundo inclui a diversidade dos saberes que existem no mundo e, portanto, das concepções, quer sobre a finitude do mundo, quer sobre a própria diversidade infinita do mundo.

O pensamento ortopédico e a razão indolente que lhe subjaz iludem esta complexidade, criando totalidades feitas de partes homogéneas. A carência a respeito da finitude transforma-se num problema técnico-científico, enquanto a carência a respeito da diversidade infinita é ignorada como um não-problema. Sabemos hoje do mal-estar que esta resposta (uma resposta fraca) nos cria. Daí a incerteza que nos assola. Não há, pois, como fugir à proposta de uma epistemologia que nos permita caminhar no meio de tanta incerteza e que permita ver esta, não como um constrangimento, mas antes como o outro lado da capacitante afirmação de uma insuspeitada e inesgotável diversidade dos saberes e das experiências humanas. Sem querer ser demasiado essencialista, poderá talvez afirmar-se, como o fez Ortega y Gasset (1987: 51), que o ser humano é um ser condenado a transformar necessidade (finitude, sustentabilidade) em liberdade (diversidade, infinitude). É certo que, mesmo que esta seja uma hipótese ontológica plausível, ela só resolve em parte o paradoxo. Deixa em aberto a questão epistemológica. Com que saberes revelar as experiências produzidas pelo pensamento ortopédico como não existentes (sociologia das ausências) ou como impossíveis (sociologia das emergências)? Como iden- 
tificar, avaliar e hierarquizar saberes tão diversos e os modos como constituem a experiência do mundo? Como articular os saberes que sabemos com os saberes que ignoramos?

\section{A urgência e a mudança civilizacional}

A segunda condição de incerteza diz especificamente respeito às alternativas culturais, políticas, sociais, económicas que podem ser pensadas e accionadas a partir da inesgotável diversidade humana, existindo num mundo finito. Se a primeira incerteza nos coloca perante o paradoxo da finitude-infinitude, a segunda incerteza coloca-nos perante o paradoxo da urgência e da mudança civilizacional. Nos últimos duzentos anos, o pensamento ortopédico, tanto à esquerda como à direita, e a razão indolente que lhe subjaz, atribuíram um sentido e uma direcção à história assentes numa concepção linear do tempo (progresso) e numa concepção evolucionista das sociedades (do subdesenvolvimento ao desenvolvimento). Com base nesta concepção, foi possível definir alternativas, determinar o movimento da história e também definir o seu fim, o estado final da evolução (idade positiva de Comte, solidariedade orgânica de Durkheim, industrialismo de Spencer, comunismo de Marx, etc., etc.). A crítica desta teoria da história está feita e dela não me ocupo aqui. Concentro-me no que ficou do colapso dela. Apesar de o colapso ser da teoria no seu todo, os mestres do pensamento ortopédico manipularam-no para reduzir a vigência da teoria à definição do último estádio: as teses do fim da história. É nesta posição que se inspiram muitas das respostas fracas que têm sido dadas às perguntas fortes que o nosso tempo nos coloca. Vimos, porém, que as respostas fracas têm vindo a causar sentimentos de exaustão, carência, mal-estar, injustiça e raiva que estão na base do distanciamento em relação ao pensamento ortopédico. Resulta daqui que a incerteza das alternativas reside não nelas em si, mas no pensamento que as descredibiliza. Como tenho vindo a defender, não precisamos de alternativas mas de um pensamento alternativo de alternativas.

Este distanciamento em relação ao pensamento ortopédico manifesta-se na recusa dos futuros por ele proposto e na afirmação difusa e aspiracional de um futuro melhor, de um outro mundo possível. ${ }^{3}$ É uma afirmação fraca porque a sua força decorre mais das suas rejeições do que das propostas alternativas. ${ }^{4}$ É a afirmação de um futuro melhor sem saber se ele é possível

\footnotetext{
3 "Um outro mundo é possível" é precisamente o mote que agrega os movimentos e as organizações sociais que, desde 2001, têm animado o Fórum Social Mundial. Ver Santos, 2005, 2008a, 2008b.

${ }^{4}$ Mais abaixo, faço uma distinção entre respostas fracas-fracas e respostas fracas-fortes e, noutro lugar, atribuo às mobilizações sociais conduzidas globalmente em nome do Fórum Social Mundial o carácter de respostas fracas-fortes. Ver Santos, 2008a e 2008b.
} 
e muito menos como será. Tem a natureza de uma utopia, mas de uma utopia muito diferente das utopias modernas. Para ela, é mais importante afirmar a possibilidade da alternativa do que definir o seu perfil. É uma exigência ética à revelia das necessidades históricas, uma luta in extremis pelo inacabamento da história. A necessidade de exigir vai de par com a incerteza do que se exige. Desta conjunção decorre a preferência pelo futuro que está à mão, por agir aqui e agora, pela actio in proximis. Esta preferência é vivida como uma necessidade que decorre da urgência de agir sob pena de ser demasiado tarde. Também aqui a nossa condição utópica diverge fundamentalmente da condição utópica moderna, que sempre se centrou num futuro tão brilhante quanto distante, na actio in distans, na submissão da táctica à estratégia.

Mas também neste domínio a condição do nosso tempo é paradoxal. Se, por um lado, domina o sentimento de urgência, por agir agora já que amanhã pode ser demasiado tarde, por outro lado, e paradoxalmente, domina a ideia de que a dimensão do que há a fazer para garantir a possibilidade de um mundo melhor implica uma mudança civilizacional, a qual só poderá ocorrer a longo prazo, uma actio in distans.

O paradoxo traduz-se na polarização entre as duas temporalidades extremas da acção colectiva de transformação social: a moldura temporal da acção urgente e a moldura temporal da mudança civilizacional. A moldura temporal da acção urgente decorre de fenómenos como o aquecimento global e a sensação de uma iminente catástrofe ecológica, a preparação mal disfarçada de uma nova guerra nuclear, a erosão das condições de sustentabilidade básica (água, por exemplo) da vida de camadas cada vez mais vastas de população, o impulso descontrolado para uma guerra eterna e a destruição injusta de tantas vidas humanas provocadas pelo esgotamento dos recursos naturais, o crescimento exponencial da desigualdade social, as novas formas de despotismo social e a emergência ou reemergência de regimes sociais regulados apenas pela força de diferenças de poder extremas ou por hierarquias estamentais de novo tipo, ditas neofeudais. Todos estes factores parecem impor que seja dada prioridade imediata à acção de curto prazo, aqui e agora, uma vez que o longo prazo pode nem sequer existir se as tendências expressas evoluírem fora de controlo. Certamente que a pressão da urgência tem origem em factores distintos no Norte global e no Sul global, mas parece estar presente em toda a parte.

Por sua vez, a moldura temporal da mudança civilizacional assenta na ideia de que as realidades do nosso tempo exigem mudanças civilizacionais mais profundas e a longo prazo. Os factos acima mencionados são sintomas de estruturas profundamente enraizadas e de organizações que não podem 
ser confrontadas por intervencionismo de curto prazo já que a lógica de tais intervenções pertence ao actual paradigma civilizacional e, portanto, só pode contribuir para o reproduzir mesmo se diz combatê-lo. O século XX provou com uma crueldade imensa que tomar o poder não é suficiente e que, em vez de tomar o poder, é necessário transformá-lo. 5

A coexistência destas polaridades temporais produz uma enorme turbulência em velhas distinções e clivagens do pensamento crítico social e político, como sejam as dicotomias entre táctica e estratégia e entre reformismo e revolução. Enquanto o sentido de urgência apela para posições tácticas e reformistas, o sentido paradigmático de mudança civilizacional apela para posições estratégicas e revolucionárias. Mas o facto de ambos os sentidos coexistirem e pressionarem conjuntamente, ainda que em direcções opostas, desfigura os termos das distinções e clivagens, tornando-os mais ou menos irrelevantes e desprovidos de sentido. Na melhor das hipóteses, transformam-se em significantes vagos, susceptíveis de apropriações contraditórias.

Se a primeira incerteza da condição do nosso tempo - a inesgotável diversidade do mundo - nos põe perante o paradoxo da finitude e infinitude, a segunda incerteza - sobre a possibilidade de um outro mundo melhor põe-nos perante o paradoxo da urgência e da mudança civilizacional. Esta dupla e paradoxal incerteza coloca-nos desafios epistemológicos e políticos novos. Para os enfrentar, socorro-me de duas tradições esquecidas da modernidade ocidental: a douta ignorância de Nicolau de Cusa e a aposta de Pascal. Foram formuladas por autores que viveram intensamente as incertezas do seu tempo e foram esquecidas porque se adequavam mal às certezas que a modernidade ocidental pretendia garantir. Estão, pois, nos antípodas do pensamento ortopédico e da razão indolente que passaram a dominar nos séculos seguintes. Foram esquecidas por eles, mas, em contrapartida, também não foram colonizadas por eles. São, pois, mais transparentes, quer quanto às suas potencialidades, quer quanto aos seus limites. Porque não partilharam da aventura moderna ocidental, permaneceram no Ocidente à margem do Ocidente. Eram inúteis e até perigosas para uma aventura que era tanto epistemológica como política: o projecto imperial do colonialismo e do capitalismo globais que criou a divisão abissal entre o que hoje designamos por Norte global e Sul global. ${ }^{6}$ Estas duas tradições são, por assim dizer, o Sul do Norte e, por isso, estão em melhores condições do que qualquer

\footnotetext{
5 As versões mais extremas desta temporalidade podem mesmo apelar à transformação do mundo sem a tomada do poder (Holloway, 2002).

${ }^{6}$ Esta divisão abissal transformou-se ela própria, numa condição epistemológica. Sobre o pensamento abissal, ver Santos, 2007.
} 
outras para aprender com o Sul global e colaborar com ele na construção de epistemologias que ofereçam alternativas credíveis ao pensamento ortopédico e à razão indolente.

\section{A douta ignorância}

Nicolau de Cusa, filósofo e teólogo, nasceu na Alemanha em 1401 e morreu em 1467. Entre 1438 e 1440, escreveu a obra intitulada A Douta Ignorância (Cusa, 2003). Confrontado com a infinitude de Deus, que não designa como tal e sim como "Máximo absoluto", o autor propõe-nos uma reflexão centrada na ideia do saber do não saber. O importante não é saber, é, sim, saber que se ignora. Diz Nicolau de Cusa, "com efeito, nenhum outro saber mais perfeito pode advir ao homem, mesmo ao mais estudioso, do que descobrir-se sumamente douto na sua ignorância, que lhe é própria, e será tanto mais douto quanto mais ignorante se souber" (2003: 5). A novidade de Nicolau de Cusa reside em que ele usa o pretexto da infinitude de Deus para propor um procedimento epistemológico geral, que vale para o conhecimento das coisas finitas, o conhecimento do mundo. Por ser finito, o nosso pensamento não pode pensar o infinito - não há proporção entre o finito e o infinito -, mas, além disso, é limitado no pensar a finitude, o mundo. Tudo o que conhecemos está sujeito a essa limitação, pelo que conhecer é, antes de tudo, conhecer essa limitação. Daí o saber do não saber.

A designação "douta ignorância" pode parecer contraditória, pois o que é douto é, por definição, não ignorante. A contradição é, contudo, aparente já que ignorar de maneira douta exige um processo de conhecimento laborioso sobre as limitações do que sabemos. Em Nicolau de Cusa há, por assim dizer, dois tipos de ignorância, a ignorância ignorante, que não sabe sequer que ignora, e a ignorância douta, que sabe que ignora e o que ignora. ${ }^{7}$ Pode pensar-se que Nicolau de Cusa se limita a repetir Sócrates, mas, de facto, assim não é. ${ }^{8}$ É que Sócrates não conhece a ideia de infinitude, que só entra no pensamento ocidental por via do neoplatonismo de raiz cristã. ${ }^{9}$ Esta

\footnotetext{
${ }^{7}$ Para Nicolau de Cusa, conhecer é medir o que se pretende conhecer. A medição tem lugar a dois níveis: o nível directo ou de primeira ordem, em que assumimos a separação absoluta entre a unidade de medida e o que se pretende medir; e o nível de segunda ordem ou reflexivo em que medimos a primeira medição. Esta reflexão revela que, sendo a unidade de medida, ela própria, um produto do conhecimento humano, aquilo que este último mede não pode ser separado em termos absolutos da medida com que o mede. É, pois, neste segundo nível que ocorre a douta ignorância. Nicolau de Cusa antecipa, assim, em cinco séculos o princípio da incerteza de Heisenberg. Ver Santos, 1987: 26. Sobre a actualidade do pensamento de Nicolau de Cusa, ver André, 2001.

${ }^{8}$ Ambos, no entanto, convergem na ideia de que o que conhecemos é muito menos importante que o que não conhecemos, sendo, pois, de privilegiar epistemologicamente a ignorância. Ver também Miller, 2002: 16.

9 Sobre este tema, ver André, 1997: 94.
} 
ideia, sujeita a múltiplas metamorfoses (progresso, emancipação), vai ser fundamental na construção do paradigma da modernidade ocidental. Mas o seu destino no interior deste paradigma é muito diferente daquele que tem no pensamento de Nicolau de Cusa. As versões dominantes do paradigma da modernidade transformaram o infinito num obstáculo a superar: o infinito é o afã infinito de o superar, controlando-o, domesticando-o, reduzindo-o a proporções finitas. Assim, a infinitude que, à partida, devia suscitar um sentimento de humildade perante ela, transforma-se no fundamento último da arrogância das versões hegemónicas do pensamento ocidental: o pensamento ortopédico e a razão indolente. Ao contrário, em Nicolau de Cusa, a infinitude é aceite enquanto tal, enquanto consciência de uma ignorância radical. Não se trata de a controlar ou dominar, mas de a reconhecer por uma dupla via: pela total ignorância que temos dela; e pelas limitações que põe à precisão do conhecimento que temos das coisas finitas. Perante ela, não é possível a arrogância, tão só a humildade. Contudo, a humildade não significa negatividade ou cepticismo. Pelo contrário, a reflexão e o conhecimento dos limites do saber contêm uma insuspeitada positividade. É que, dialecticamente, e como afirma João Maria André, reconhecer os limites é, de algum modo, estar para além deles (1997: 94). O facto de não ser possível atingir a verdade com precisão não nos dispensa de a buscar. Ao contrário, o que está para além dos limites (a verdade) comanda o que é possível e exigível dentro dos limites (a veracidade, enquanto busca da verdade).

Sem surpresa, quase seis séculos depois, a dialéctica da finitude/infinitude, que caracteriza o tempo presente, é muito diferente da de Cusa. A infinitude com que nos debatemos não é transcendental $;{ }^{10}$ decorre da inesgotável diversidade da experiência humana e dos limites para a conhecer. No nosso tempo, a douta ignorância será um laborioso trabalho de reflexão e de interpretação sobre esses limites, sobre as possibilidades que eles nos abrem e as exigências que nos criam. Acresce que da diversidade da experiência humana faz parte a diversidade dos saberes sobre a experiência humana. A nossa infinitude tem, pois, uma contraditória dimensão epistemológica: uma pluralidade infinita de saberes finitos sobre a experiência humana no mundo. A finitude de cada saber é, assim, dupla, constituída pelos limites do que conhece sobre a experiência do mundo e pelos limites (quiçá bem maiores) do que conhece sobre os outros saberes do mundo e, portanto, sobre o conhecimento do mundo que outros saberes

${ }^{10}$ A incerteza da infinitude transcendental não desapareceu, mas permanece nas margens ou zonas de fronteira criadas pela hegemonia do secularismo moderno. Sobre este tema ver Santos, no prelo. 
proporcionam. É sobretudo a diversidade epistemológica do mundo que causa incerteza no tempo actual. O saber que ignora é o saber que ignora os outros saberes que com ele partilham a tarefa infinita de dar conta das experiências do mundo. O pensamento ortopédico e a razão indolente não podem guiar-nos adequadamente nesta incerteza porque fundam um saber (a ciência moderna na concepção hegemónica que temos dela) que conhece mal os limites do que permite conhecer da experiência do mundo e conhece ainda menos os outros saberes que com ele partilham a diversidade epistemológica do mundo. Aliás, mais do que não conhecer os outros saberes, recusa reconhecer sequer que eles existam. Entre as experiências disponíveis do mundo produzidas como não existentes, assumem particular importância os saberes que não cabem no pensamento ortopédico e na razão indolente. Por isso, uma das dimensões principais da sociologia das ausências é a sociologia dos saberes ausentes, ou seja, a identificação dos saberes produzidos como não existentes pela epistemologia hegemónica.

Ser um douto ignorante no nosso tempo é saber que a diversidade epistemológica do mundo é potencialmente infinita e que cada saber só muito limitadamente tem conhecimento dela. Também neste aspecto a nossa condição é diferente da de Nicolau de Cusa. Enquanto o saber do não saber de que ele parte é um saber único e, portanto, uma única douta ignorância, a douta ignorância adequada ao nosso tempo é infinitamente plural. Mas, tal como acontece com a douta ignorância de Nicolau de Cusa, a impossibilidade de captar a infinita diversidade epistemológica do mundo não nos dispensa de procurar conhecê-la, pelo contrário, exige-o. A essa exigência chamo a ecologia de saberes. Por outras palavras, se a verdade só existe como busca da verdade, o saber só existe como ecologia de saberes. ${ }^{11}$ Conhecidas as diferenças que nos separam de Nicolau de Cusa, torna-se mais fácil aprender a lição que ele nos dá. Ela só é frutífera se formos para além dele e o pusermos ao serviço das nossas preocupações e incertezas, seguramente diferentes das dele.

\section{A ecologia de saberes}

Sendo infinita, a pluralidade de saberes existentes no mundo é inatingível enquanto tal, já que cada saber só dá conta dela parcialmente, a partir da sua perspectiva específica. Mas, por outro lado, como cada saber só existe nessa pluralidade infinita de saberes, nenhum deles pode compreender-se a si próprio sem se referir aos outros saberes. O saber só existe como pluralidade de saberes, tal como a ignorância só existe como pluralidade de ignorâncias. As possibilidades e os limites de compreensão e de acção de

${ }_{11}$ Sobre este tema, ver Santos, 2006: 87-126. 
cada saber só podem ser conhecidas na medida em que cada saber se propuser uma comparação com outros saberes. Essa comparação é sempre uma versão contraída da diversidade epistemológica do mundo, já que esta é infinita. É, pois, uma comparação limitada, mas é também o modo de pressionar ao extremo os limites e, de algum modo, de os ultrapassar ou deslocar. Nessa comparação consiste o que designo por ecologia de saberes.

Os limites e as possibilidades do que um dado tipo de saber permite conhecer sobre uma dada experiência humana decorrem de esta ser também conhecida por outros saberes que esse saber ignora. Os limites e as possibilidades de cada saber residem, assim, em última instância, na existência de outros saberes e, por isso, só podem ser explorados e valorizados na comparação com outros saberes. Quanto menos um dado saber conhecer os limites do que conhece sobre os outros saberes, tanto menos conhece os seus próprios limites e possibilidades. A comparação não é fácil, mas nela reside a douta ignorância adequada ao nosso tempo.

A dificuldade da comparação reside em que as relações entre saberes são assombradas por uma assimetria. Em princípio, cada saber conhece mais e melhor os seus limites e possibilidades e do que os limites e possibilidades de outros saberes. Esta assimetria constitui o que chamo diferença epistemológica. Ela ocorre nas relações entre saberes vigentes na mesma cultura e ainda mais intensamente nas relações entre saberes vigentes em diferentes culturas. Esta assimetria é complexa porque, sendo epistemológica, manifesta-se menos como uma questão epistemológica do que como uma questão política. Ou seja, a assimetria entre os saberes ocorre sobreposta à assimetria dos poderes. Em termos de tipos-ideais, há dois modos opostos de accionar essa assimetria. A primeira consiste em maximizá-la, levando ao máximo a ignorância a respeito dos outros saberes, ou seja, declarando a sua inexistência. A este modo chamo fascismo epistemológico porque constitui uma relação violenta de destruição ou supressão de outros saberes. Trata-se de uma afirmação de força epistemológica que oculta a epistemologia da força. $\mathrm{O}$ fascismo epistemológico existe sob a forma de epistemicídio, cuja versão mais violenta foi a conversão forçada e a supressão dos conhecimentos não ocidentais levadas a cabo pelo colonialismo europeu e que continuam hoje sob formas nem sempre mais subtis. No pólo oposto, está a tentativa de minimizar ao máximo essa assimetria na relação entre saberes. A complexidade desta tentativa decorre de ela não poder ser realizada com êxito unilateralmente por um dado saber. Pelo contrário, pressupõe que a assimetria seja reconhecida por outros saberes e que todos façam dela o motor da comparação com outros saberes. Por outras palavras, a diferença epistemológica só pode ser minimizada através de compara- 
ções recíprocas entre saberes na busca de limites e possibilidades cruzadas. A este segundo modo de viver a assimetria chamo a ecologia de saberes. Da análise precedente, decorre que o primeiro modo tem predominado nas epistemologias hegemónicas da modernidade ocidental e nos modos de racionalidade e de pensamento que elas sustentam, a razão indolente e o pensamento ortopédico. A proposta que faço, da ecologia de saberes, é a epistemologia da douta ignorância.

A ecologia de saberes confronta-se com dois problemas: a) como comparar saberes, dada a diferença epistemológica; b) como criar o conjunto de saberes que participa de um dado exercício de ecologia de saberes já que a pluralidade de saberes é infinita. Para confrontar o primeiro, proponho a tradução e, para confrontar o segundo, proponho a artesania das práticas.

\section{A tradução}

Por ter tratado deste tema noutro lugar (Santos, 2006: 127-154), limito-me aqui a uma breve referência. Pautado pela douta ignorância, cada saber conhece melhor os seus limites e possibilidades comparando-se com outros saberes. A existência da diferença epistemológica faz com que a comparação tenha de ser feita através de procedimentos de busca de proporção e correspondência que, no conjunto, constituem o trabalho de tradução. Como referi, para que estes procedimentos actuem é necessário que eles sejam levados a cabo por todos os saberes que compõem um dado círculo de ecologia de saberes. Na acepção que aqui lhe dou, a tradução é tradução recíproca. Através dela, a diferença epistemológica, ao ser assumida por todos os saberes em presença, torna-se uma diferença tendencialmente igual. Os procedimentos de proporção e correspondência são procedimentos indirectos que permitem aproximações sempre precárias ao desconhecido a partir do conhecido, ao estranho a partir do familiar, ao alheio a partir do próprio. Entre eles, menciono sinais, símbolos, conjecturas, enigmas, pistas, perguntas, paradoxos, ambiguidades, etc. ${ }^{12} \mathrm{O}$ uso recíproco destes procedimentos, longe de eliminar a incompletude de cada saber, aumenta-a. A douta ignorância consiste precisamente em levar ao máximo a consciência dessa incompletude. $\mathrm{O}$ aumento da incompletude resulta da astúcia da douta ignorância. $\mathrm{O}$ exercício reiterado da tradução vai revelando que os

\footnotetext{
12 Também aqui haveria muito a aprender com uma outra tradição ocidental esquecida ou marginalizada, a reflexão filosófica realizada na primeira modernidade ocidental (século XVI-XVII), a modernidade ibérica, em especial a reflexão filosófica dos Conimbricences, os jesuítas (mas também os dominicanos) que ensinaram filosofia no Colégio das Artes da Universidade de Coimbra a partir de 1555. Especificamente a respeito da reflexão dos Conimbricences sobre os sinais - que tanto inspirou a semiótica de Charles Sanders Peirce -, ver Doyle, 2001.
} 
procedimentos desenvolvidos para conhecer outros saberes são os mesmos com que cada saber conhece a experiência do mundo em geral e não apenas a experiência epistemológica do mundo.

Os procedimentos da tradução, ainda que basicamente os mesmos, variam consoante os diferentes saberes pertencem à mesma cultura ou a culturas diferentes. Neste último caso, a tradução assume a forma de tradução intercultural e o seu exercício é particularmente complexo.

\section{A artesania das práticas}

Tal como o fascismo epistemológico, a ecologia de saberes é uma opção epistemológica e política. Sendo sempre limitado o conjunto de saberes que integra a ecologia dos saberes, há que definir como se constituem esses conjuntos. À partida, é possível um número ilimitado de ecologias de saberes, tão ilimitado quanto o da diversidade epistemológica do mundo. Cada exercício de ecologia de saberes implica uma selecção de saberes e um campo de interacção onde o exercício tem lugar. Um e outro são definidos em função de objectivos não epistemológicos. A incerteza sobre a diversidade inesgotável da experiência do mundo decorre de uma preocupação em não desperdiçar a experiência do mundo num contexto em que este parece ter esgotado a capacidade de inovação libertadora. Do mesmo modo, a incerteza sobre a possibilidade e a natureza de um mundo melhor decorre de um sentimento contraditório de urgência e de mudança civilizacional a respeito de uma exigência de transformação social. Desta dupla preocupação, nasce o impulso para a ecologia de saberes e os contextos específicos em que a preocupação ocorre determinam os saberes que integrarão um dado exercício de ecologia dos saberes. A preocupação da preservação da biodiversidade pode levar a uma ecologia entre o saber científico e o saber camponês ou indígena. ${ }^{13}$ A preocupação da luta contra a discriminação pode conduzir a uma ecologia entre saberes produzidos por diferentes movimentos sociais: feministas, anti-racistas, de orientação sexual, de direitos humanos, indígenas, afrodescendentes, etc., etc. A preocupação com a dimensão espiritual da transformação social pode levar a ecologias entre saberes religiosos e seculares, entre ciência e misticismo, entre teologias da libertação (feministas, pós-coloniais) e filosofias ocidentais, orientais, indígenas, africanas, etc. A preocupação com a dimensão ética e artística da transformação social pode incluir todos esses saberes e ainda as humanidades, no seu conjunto, a literatura e as artes.

${ }_{13}$ Especificamente sobre a nova relação ecológica entre ciência e outros saberes, ver Santos, 2003 (org.) e Santos, Meneses e Nunes, 2004: 19-101. 
As preocupações que suscitam os exercício de ecologia de saberes são partilhadas por diversos grupos sociais que, em dado contexto, convergem na ideia de que as suas aspirações e os seus interesses só podem ser prosseguidos com êxito em articulação com outros grupos sociais e, portanto, com os saberes dos outros grupos sociais. A ecologia de saberes é a dimensão epistemológica de uma solidariedade de tipo novo entre actores ou grupos sociais. É uma solidariedade internamente diversa em que cada grupo apenas se mobiliza por razões próprias e autónomas de mobilização, mas, por outro lado, entende que as acções colectivas que podem transformar essas razões em resultados práticos extravasam do que é possível levar a cabo por um só actor ou grupo social. A ecologia de saberes sinaliza a passagem de uma política de movimentos sociais para uma política de inter-movimentos sociais.

Esta caracterização das razões que criam a necessidade da ecologia de saberes e seleccionam os saberes que, numa situação concreta, a integram ajuda-nos igualmente a identificar os campos de interacção em que a ecologia de saberes ocorre. Esses campos não são epistemológicos. Os saberes que dialogam, que mutuamente se interpelam, questionam e avaliam, não o fazem em separado como uma actividade intelectual isolada de outras actividades sociais. Fazem-no no contexto de práticas sociais constituídas ou a constituir, cuja dimensão epistemológica é uma entre outras, e é dessas práticas que emergem as questões postas aos vários saberes em presença. Tais questões só são epistemológicas na medida em que forem práticas, isto é, tiverem consequências para o contexto das práticas em que a ecologia de saberes tem lugar. Daí que os saberes sejam confrontados com problemas que, por si, nunca poriam. Em geral, tais problemas tomam os saberes de surpresa e estes, com frequência, revelam-se incapazes de os resolver. A interpelação cruzada dos saberes nasce do reconhecimento dessa incapacidade e da tentativa de a superar.

Esta prioridade das práticas produz uma transformação fundamental na relação entre os saberes em presença. A superioridade de um dado saber deixa de ser definida pelo nível de institucionalização e profissionalização desse saber para passar a ser definida pelo seu contributo pragmático para uma dada prática. Fica assim desactivado um dos motores do fascismo epistemológico que tem caracterizado a relação da ciência moderna com outros saberes. Para certas práticas, a ciência será certamente determinante, tal como para outras será irrelevante ou até contraproducente. Esta deslocação pragmática das hierarquias entre saberes não elimina as polarizações entre os saberes, mas redu-las às que decorrem dos contributos práticos para a acção almejada. Neste sentido, a ecologia de saberes transforma todos os 
saberes em saberes experimentais. Também aqui a lição de Nicolau de Cusa é frutífera. Em 1450 redigiu três diálogos, De Sapientia, De Mente e De Staticis Experimentis, em que a personagem central é o Idiota, um homem simples e iletrado, um pobre artesão que faz colheres de pau. ${ }^{14}$ Nos diálogos que ele tem com o filósofo credenciado (o humanista, o orador), ele é o sábio capaz de resolver os problemas mais complexos da existência a partir da experiência da sua vida activa, à qual é conferida prioridade em relação à vida contemplativa. Como afirma Leonel dos Santos (2002: 73), "O Idiota é contraposto ao homem erudito e letrado, possuidor de um saber escolar, fundado em autores e autoridades, e que destes tira a sua competência, mas que perdeu o sentido do uso e cultivo autónomo das suas próprias faculdades". O Orador provoca o Idiota: "Que presunção é a tua, pobre idiota completamente ignorante, que assim minimizas o estudo das letras, sem o qual ninguém progride?" (2002: 78). O Idiota responde: "Não é, grande Orador, presunção o que me não deixa calado mas a caridade. Pois vejo-te dedicado à busca da sabedoria com muito trabalho em vão... A opinião da autoridade fez de ti, que és livre por natureza, algo semelhante a um cavalo preso pelo cabresto à manjedoura, que só come aquilo que lhe é servido. O teu conhecimento alimenta-se da autoridade dos que escrevem, limitado a um pasto alheio e não natural" (2002: 79). Pouco depois acrescenta: "Eu, porém, digo-te que a sabedoria grita nos mercados e o seu clamor anda pelas praças" (2002: 79). A sabedoria exprime-se no mundo e nas tarefas mundanas, particularmente naquelas que são obra da razão e que implicam operações de cálculo, de medida e de pesagem (2002: 81).

São diálogos muito irónicos, em que o Idiota é afinal o expositor da douta ignorância proposta por Nicolau de Cusa. ${ }^{15}$ Neles, as grandes disputas entre escolas de saber erudito deixam de ser importantes se a sua importância para a vida e para a experiência práticas não for demonstrada. Este descentramento dos saberes é fundamental para que a ecologia de saberes atinja os seus objectivos: a promoção de práticas sociais eficazes e libertadoras a partir da interpelação cruzada dos limites e das possibilidades de cada um dos saberes em presença.

O descentramento dos saberes tem ainda uma outra dimensão. O campo de interacções práticas (isto é, com objectivos práticos), em que se realiza a ecologia de saberes, exige que o lugar da interpelação dos saberes não seja um lugar exclusivo dos saberes, por exemplo, universidades ou centros de

\footnotetext{
${ }_{14}$ Sobre os diálogos e a "sabedoria do idiota" ver Santos, Leonel (2002: 67-98)

${ }^{15}$ De perspectivas muito diferentes da de Nicolau de Cusa, a ideia de privilegiar a ignorância como princípio pedagógico tem sido tratada por muitos autores. Ver, por exemplo, Rancière, 1987.
} 
investigação. O lugar de enunciação da ecologia de saberes são todos os lugares onde o saber é convocado a converter-se em experiência transformadora. Ou seja, são todos os lugares que estão para além do saber enquanto prática social separada. Significativamente, os diálogos de Nicolau de Cusa têm lugar ou no barbeiro ou na humilde oficina do artesão. O filósofo é, pois, levado a discutir num terreno que lhe não é familiar e para o qual não foi treinado, o terreno da vida prática. É o terreno onde se planeiam acções práticas, se calculam as oportunidades, se medem os riscos, se pesam os prós e os contras. É este o terreno da artesania das práticas, o terreno da ecologia de saberes.

Em conclusão, a douta ignorância e a ecologia dos saberes são as vias para enfrentar uma das condições de incerteza do nosso tempo: a diversidade infinita da experiência humana e o risco que se corre de, com os limites de conhecimento de cada saber, se desperdiçar experiência, isto é, de se produzir como inexistentes experiências sociais disponíveis (sociologia das ausências) ou de se produzir como impossíveis experiências sociais emergentes (sociologia das emergências).

\section{A aposta de Pascal}

Para enfrentar a segunda condição de incerteza do tempo presente - a incerteza de não sabermos se o mundo melhor a que julgamos ter direito e de que necessitamos com urgência será efectivamente possível - proponho outra sugestão filosófica da modernidade ocidental igualmente esquecida: a aposta de Pascal. Partilhando o mesmo esquecimento e marginalização a que foi sujeita a douta ignorância de Nicolau de Cusa, a aposta de Pascal pode, tal como a douta ignorância, servir de ponte ou de abertura para outras filosofias não ocidentais e para outras práticas de interpelação e de transformação social que não as que vieram a ser sufragadas pelo pensamento ortopédico e pela razão indolente. Aliás, entre a douta ignorância e a aposta há uma afinidade básica. Ambas assumem a incerteza e a precariedade do saber como uma condição que, sendo um constrangimento e uma fraqueza, é também uma força e uma oportunidade. Ambas se debatem com a "desproporção" entre o finito e o infinito e ambas procuram elevar ao limite máximo as potencialidades do que é possível pensar e fazer dentro dos limites do finito.

Pascal parte de uma incerteza radical: a existência de Deus não pode ser demonstrada racionalmente. Diz Pascal: "Se há um Deus, ele é infinitamente incompreensível, uma vez que, não tendo nem partes nem limites, não tem qualquer comparação connosco. Somos, portanto, incapazes de saber o que ele é e se existe" (1988: 103). Em face disso, põe a questão de saber como 
formular razões que levem um não-crente a mudar de opinião e passar a acreditar em Deus. A resposta é a aposta. Apesar de não podermos racionalmente determinar que Deus existe, podemos pelo menos encontrar um meio racional de determinar que apostar na sua existência nos traz mais vantagens do que acreditar na sua não existência. A aposta envolve um risco certo e finito de ganhar ou perder e a possibilidade de obter um ganho infinito. Apostar na existência de Deus obriga-nos a ser honestos e virtuosos. E, claro, também nos obriga a renunciar a prazeres nocivos e à glória mundana. Se Deus não existir, perdemos a aposta mas em compensação ganhámos uma vida virtuosa, cheia de boas obras. Em contrapartida, se ele existir, o nosso ganho é infinito, a salvação eterna. De facto, não perdemos nada com esta aposta e o ganho pode ser infinito: "[...] a cada passo que derdes neste caminho vereis tanta certeza de ganho, e tão grande o nada que arriscais, que reconhecereis, por fim, que haveis apostado numa coisa certa, infinita, pela qual nada haveis dado" (1988: 107)

A racionalidade da aposta consiste em que, para apostar na existência de Deus, não é preciso ter fé. É, contudo, uma racionalidade muito limitada, pois nada nos diz sobre a real existência de Deus e muito menos sobre a sua natureza. Como a existência e natureza de Deus é sempre um acto de fé, Pascal tem de encontrar uma mediação entre a fé e a racionalidade. Essa mediação é o hábito. Diz Pascal: "O costume é a nossa natureza. Quem se acostuma à fé crê nela” (1988: 50). Ou seja, o apostador, ao apostar reiteradamente na existência de Deus, acabará por acreditar nela.

Tal como aconteceu com Nicolau de Cusa, a preocupação que decorre da incerteza do nosso tempo é muito diferente da de Pascal. Para a grande maioria, o que está em causa não é a salvação eterna, o mundo do além, mas antes um mundo terreno melhor do que o mundo actual. Não havendo necessidade ou determinismo na história, não há nenhuma maneira racional de saber ao certo se um outro mundo é possível e muito menos como será a vida nele. O nosso infinito é a incerteza infinita a respeito da possibilidade ou não de um outro mundo melhor. Perante isto, a questão que nos confronta pode ser formulada assim: que razões nos podem levar a lutar por uma tal possibilidade, correndo riscos certos para obter um ganho tão incerto? Sugiro que a resposta seja a aposta, como única alternativa tanto às teses do fim da história como às teses do determinismo vulgar. A aposta é a metáfora da construção precária, mas minimamente credível, da possibilidade de um mundo melhor, ou seja, a possibilidade de emancipação social, sem a qual a rejeição da injustiça do mundo actual e o inconformismo perante ela não fazem sentido. A aposta é a metáfora da transformação social num mundo em que as razões e visões negativas (o que se rejeita) são muito 
mais convincentes do que as razões positivas (a identificação do que se quer e como lá chegar).

Acontece que a aposta do nosso tempo sobre a possibilidade de um mundo melhor é muito diferente da aposta de Pascal e bem mais complexa. São diferentes as condições da aposta e a proporção entre os riscos de ganhar e os riscos de perder. O que há de comum entre Pascal e nós são os limites da racionalidade, a precariedade dos cálculos e a consciência dos riscos. Quem é o apostador no nosso tempo? Enquanto para Pascal o apostador é o indivíduo racional, no nosso tempo o apostador é a classe ou o grupo social excluído, discriminado, em suma, oprimido e os seus aliados. Porque a possibilidade de um mundo melhor ocorre neste mundo, só aposta nessa possibilidade quem tem razões para rejeitar o status quo do mundo actual. Os opressores tendem a experienciar o mundo em que vivem como o melhor possível e o mesmo acontece com aqueles que, não sendo directamente opressores, beneficiam das práticas opressivas destes. Para eles não faz sentido apostar no que já existe.

Dado o carácter transicional do nosso tempo há a considerar uma distinção no seio do grupo dos oprimidos e seus aliados. Trata-se da distinção entre aqueles que se formaram na convicção da necessidade determinística de um mundo melhor (a ilusão do futuro), para quem, por isso, nunca fez sentido apostar, e aqueles que, mais fustigados pela opressão ou mais sujeitos à doutrinação dos opressores, não acreditam na possibilidade, por mais remota, de um outro mundo melhor (a ilusão do presente), e, portanto, para quem não faz agora sentido apostar mesmo se no passado fez. Quanto aos primeiros, as razões para apostar estarão associadas à desilusão do determinismo do futuro; quanto aos segundos, as razões estarão associadas à desilusão do determinismo do presente.

Também as condições da aposta do nosso tempo divergem muito das da aposta de Pascal. Enquanto, para o apostador de Pascal, a existência ou não de Deus não depende dele, para o apostador do nosso tempo a possibilidade ou não de um mundo melhor depende da sua aposta e das acções que resultarem dela. Mas, paradoxalmente, os seus riscos são maiores. É que as acções que resultarem da aposta ocorrerão num mundo de classes e grupos em conflito, de opressores e de oprimidos, e, por isso, encontrarão resistências e serão objecto de retaliação. Os riscos (as possibilidades de perda) são, assim, duplos: os riscos decorrentes da luta contra a opressão; e os riscos decorrentes do facto de, afinal, um outro mundo melhor não ser possível. Daí que não seja convincente no nosso tempo a demonstração que Pascal faz ao seu apostador: "[...] por toda a parte onde está o infinito e onde há uma infinidade de probabilidades de perda contra a de ganho, não há que hesitar: é preciso dar tudo" (1988: 105). 
Pelo contrário, no nosso tempo, há muitas razões para hesitar e para não arriscar tudo. São o outro lado da prevalência das razões negativas sobre as razões positivas. Daqui decorrem várias consequências para o projecto da aposta na emancipação social. A primeira diz respeito à pedagogia da aposta. Ao contrário da aposta de Pascal, as razões para apostar na emancipação social não são transparentes. Para se tornarem convincentes, devem ser objecto de argumentação e de persuasão. Em vez da racionalidade demonstrativa da aposta, a razoabilidade argumentativa da aposta. A pedagogia da aposta deve ter lugar em conformidade com a ecologia de saberes, nos contextos e campos de interacção em que esta opera. Trata-se, em suma, de um projecto de educação popular em que o conhecimento académico e a ciência podem participar, desde que o façam nos termos da ecologia de saberes. ${ }^{16}$ A pedagogia variará segundo o lugar e o contexto da sua prática e também segundo o tipo de apostadores. Por exemplo, em referência à distinção feita acima, a pedagogia da aposta visa, no caso da ilusão do futuro, transformar a necessidade do futuro na liberdade do presente, e, no caso da ilusão do presente, transformar a necessidade do presente na liberdade do futuro. Em ambos os casos, a pedagogia da aposta visa transformar uma negação dialéctica - quer o mundo actual seja visto como antítese ou com síntese numa negação ética.

A segunda consequência diz respeito às relações entre razão e paixão. Enquanto Pascal incita o apostador a diminuir as suas paixões, já que estas o impedem de reconhecer as razões que justificam a aposta, o apostador do nosso tempo precisa de complementar as razões da aposta, e consequentemente da luta pela emancipação social, com as paixões da aposta e da aspiração de emancipação social. As paixões razoáveis ${ }^{17}$ intensificam a razoabilidade das razões da aposta, sedimentam a indignação e o inconformismo ante a injustiça e fortalecem a coragem para enfrentar os riscos de lutar contra os interesses instalados.

A terceira consequência da condição da aposta do nosso tempo diz respeito ao tipo de acções que decorrem da aposta. A radical incerteza do futuro melhor e os riscos inerentes à luta por ele levam a privilegiar as acções que incidam no quotidiano e se traduzam em melhorias aqui e agora na vida dos oprimidos e excluídos. Por outras palavras, a aposta privilegia a actio in proximis. Este tipo de acção reforça, pelo seu êxito, a vontade da aposta

\footnotetext{
${ }^{16} \mathrm{Um}$ tal projecto de educação popular subjaz à proposta de criação da universidade popular dos movimentos sociais que tenho vindo a defender. Ver Santos, 2006: 155-165.

${ }_{17}$ As paixões dizem-se razoáveis porque são complementares da razão. Mas a verdade é que elas só serão eficazmente razoáveis se a razão for apaixonada, ou seja, se a razão e a paixão se deixarem interpenetrar.
} 
e satisfaz o sentimento da urgência da transformação do mundo que referi acima, o sentimento de que é preciso actuar já sob pena de mais tarde ser demasiado tarde. A aposta não se adequa à actio in distans, pois esta constituiria um risco infinito perante uma incerteza infinita. Isto não significa que tal acção não esteja presente. Só que não está presente nos seus próprios termos. As transformações do quotidiano só ratificam a aposta na medida em que também são sinais da possibilidade de emancipação social. Para isso, devem ser radicalizadas e, ao serem-no com êxito, respondem ao sentimento da necessidade de mudança civilizacional para que um outro mundo melhor seja possível. A radicalização consiste na busca dos aspectos subversivos e criativos do quotidiano e que podem ocorrer na mais básica luta pela sobrevivência. ${ }^{18}$ As transformações do quotidiano têm, assim, uma dupla valência: as melhorias concretas do quotidiano e os sinais que estas dão de possibilidades bem mais amplas. É por via destes sinais que a actio in distans se faz presente na actio in proximis. Por outras palavras, a actio in distans só existe como dimensão da actio in proximis, como vontade e razão da radicalização da acção. Através da aposta, torna-se possível juntar quotidiano e utopia sem, no entanto, os dissolver um no outro. A utopia é o que falta ao quotidiano para nos dispensar de pensar na utopia. O ser humano não é apenas o ser humano e a sua circunstância, como ensina Ortega y Gasset, é também o ser humano e o que falta na sua circunstância para ele ser plenamente humano.

\section{Conclusão: de respostas fracas-fracas às respostas fracas-fortes}

Enquanto não confrontarmos os problemas, as incertezas e as perplexidades próprios do nosso tempo, estaremos condenados a neo-ismos e a pós-ismos, ou seja, a interpretações do presente que só têm passado. O distanciamento que propus em relação às teorias e disciplinas, construídas pelo pensamento ortopédico e a razão indolente, assenta no facto de elas terem contribuído para a discrepância entre perguntas fortes e respostas fracas que caracteriza o nosso tempo. Essa discrepância traduz-se em grandes incertezas, entre as quais salientei duas principais: a incapacidade de captar a inesgotável diversidade da experiência humana e o temor que com isso se desperdice experiência que nos poderia ser preciosa para resolver alguns dos nossos problemas; e a incerteza decorrente da aspiração a um mundo melhor sem que disponhamos de uma teoria da história que nos indique que ele é necessário ou sequer possível. Para enfrentar estas incertezas, propus duas sugestões

${ }_{18}$ Sobre o quotidiano enquanto elemento intrínseco da realidade e da acção transformadora, ver Isasi-Díaz, 2003: 365-385. 
epistemológicas construídas com base em duas tradições particularmente ricas da modernidade ocidental, ambas marginalizadas e esquecidas pelo pensamento ortopédico e a razão indolente que têm vindo a dominar nos últimos dois séculos: a douta ignorância, com a ecologia dos saberes que dela decorre, e a aposta. Ambas revelam que o conhecimento erudito ou académico tem uma relação ingénua com o conhecimento que considera ingénuo. Ambas revelam a precariedade do saber (saber que ignora) e a precariedade do agir (apostar com base em cálculos limitados).

Como penso ter mostrado, estas propostas não visam eliminar as incertezas do nosso tempo. Visam antes assumi-las plenamente e usá-las produtivamente, transformando-as de constrangimento em oportunidade. Pode dizer-se que, em certo sentido, são respostas fracas. Em face disto, é necessário fazer uma distinção conceptual entre respostas fracas-fortes e respostas fracas-fracas.

Existem dois tipos de respostas fracas. O primeiro tipo é aquilo que denomino de resposta fraca-forte. Parafraseando Lucien Goldmann (1966, 1970), esta resposta representa o máximo de consciência possível de uma dada época. Transforma a perplexidade provocada pela pergunta forte em energia e valor positivos. Em vez de assumir que a perplexidade é inútil ou que pode ser eliminada por uma resposta simples, transforma a perplexidade num sintoma de complexidade implícita. Assim, a perplexidade transforma-se na experiência social de um novo campo aberto de contradições onde existe uma competição relativamente desregulada entre as diferentes possibilidades. Sendo os resultados desta competição muito incertos, existe lugar de sobra para a inovação social e política, logo que a perplexidade seja transformada na capacidade de viajar sem mapas fiáveis.

O outro tipo de resposta fraca é a resposta fraca-fraca. Representa o mínimo de consciência possível de uma determinada época. Descarta e estigmatiza a perplexidade como sintoma de um fracasso na compreensão de que o real coincide com o possível, valorizando as soluções hegemónicas como um produto "natural" da sobrevivência dos mais aptos. A perplexidade é, neste caso, vista como uma debilidade decorrente da recusa em viajar de acordo com mapas historicamente testados. Porque os mapas não podem ser questionados, a resposta fraca-fraca convida ao imobilismo e, portanto, à rendição. Inversamente, a resposta fraca-forte é um convite para um movimento de alto risco.

As respostas fracas que mencionei no início deste trabalho são respostas fracas-fracas. Pelo contrário, a douta ignorância, a ecologia dos saberes e a aposta são respostas fracas-fortes. Ainda que ocidentais na sua origem, representam uma racionalidade muito mais ampla (porque muito mais cons- 
ciente dos seus limites) do que a que veio a dominar. Porque marginalizadas e esquecidas, mantiveram uma abertura a outras tradições e problemáticas não ocidentais que a modernidade ocidental foi perdendo à medida que ficou refém do pensamento ortopédico e da razão indolente. Porque marginalizadas e esquecidas, estas tradições tiveram um destino semelhante ao de muitos saberes e tradições não ocidentais e, por isso, estão hoje em melhores condições para aprender com eles e para, em conjunção com eles, contribuírem para as ecologias de saberes e para a interculturalidade.

A douta ignorância e a aposta, ainda que respondendo às incertezas criadas pelas concepções e práticas hegemónicas da modernidade ocidental, têm uma versatilidade e uma abertura que lhes permite serem utilizadas em contextos geopolíticos diferentes. Mas com uma ressalva importante de natureza geopolítica. Estas propostas implicam des-pensar ou desaprender o pensamento ortopédico e a razão indolente, o que procurei ilustrar com a metáfora das filosofias à venda que recolhi de um "bárbaro civilizado", capaz de ver a barbárie da civilização, Luciano de Samósata. No entanto, des-pensar e desaprender assumem formas muito distintas no Norte global e no Sul global, já que o pensamento ortopédico e a razão indolente têm sido os instrumentos que justificam a divisão Norte/Sul e a dominação imperial do Norte global sobre o Sul global. Em parte, a dominação tem consistido na imposição do des-pensamento e da desaprendizagem de saberes não ocidentais ou não imperiais, ou seja, na imposição de monopólios analíticos que produzem ausências e desperdiçam experiência. Com base no pensamento ortopédico, o Norte global só conhece do Sul global o que pode justificar a continuação da dominação sobre ele. Por isso, des-pensar e desaprender no Sul global visa sobretudo reinventar ou reabilitar, como sábios e válidos, saberes e experiências que o pensamento ortopédico e a razão indolente declararam ignorantes e produziram como ausentes. No Norte global, des-pensar e desaprender visa sobretudo aprender a ignorar. Uma boa metáfora disso mesmo é-nos oferecida por Luciano de Samósata: os filósofos podem ficar escandalizados por ver reunidas no mesmo lote de venda filosofias tão opostas como as de Heraclito e Demócrito, mas o comerciante que se aproxima de Zeus e de Hermes para as comprar pode ter boas razões para ver nelas uma complementaridade útil.

Por outro lado, o facto de a douta ignorância, a ecologia de saberes e a aposta privilegiarem, como lugar de enunciação, o quotidiano, onde a reflexão e a acção não se separam, permite ter presentes as abissais diferenças do quotidiano no Norte global e no Sul global. Essas diferenças são activamente ocultadas pelas abstracções conceptuais do pensamento ortopédico, com base nas quais se constroem os universalismos que intensificam a domi- 
nação na medida em que a eliminam conceptualmente. Pelo contrário, no quotidiano os conhecimentos e os conceitos purificados são devolvidos à vida donde emergiram e onde estiveram antes de serem o que são. Coladas à vida, a douta ignorância, a ecologia de saberes e a aposta são práticas de conhecimento que ocorrem no contexto de outras práticas, tal como, metaforicamente, a sabedoria do Idiota de Nicolau de Cusa se exercita na barbearia ou na oficina do artesão. Esta contextualização obriga a ter presente que o quotidiano da grande maioria da população do Sul global - que inclui o Sul global que existe no interior do Norte global, o "terceiro mundo interior" - é uma luta incessante pela sobrevivência e pela libertação frente às imposições com que o Norte global e a sua epistemologia imperial exercem a sua dominação sobre o Sul global. A douta ignorância é uma luta contra a ignorância ignorante do Norte global em relação ao Sul global; tal como a ecologia de saberes visa a construção de um senso comum emancipatório enquanto autoconsciência da luta contra a opressão; tal como a aposta tem presente que os apostadores habitam no Sul global ou assumem radicalmente a solidariedade com os que habitam no Sul global.

Da douta ignorância, ecologia dos saberes e aposta não emerge um tipo de emancipação social, nem sequer uma tipologia de emancipações sociais. Emerge tão só a razoabilidade e a vontade de luta por um mundo melhor e uma sociedade mais justa, um conjunto de saberes e de cálculos precários animados por exigências éticas e por necessidades vitais. A luta pela sobrevivência e libertação contra a fome e a violência é o grau zero da emancipação social e, nessas situações, é também o seu grau máximo. A emancipação social é algo como a "arte perfectoria" do sábio idiota de Nicolau de Cusa, que faz colheres de madeira sem se poder limitar a imitar a natureza (não há colher na natureza), mas também sem nunca atingir com precisão a ideia da coclearidade (a essência da colher, que pertence à "arte divina"). A emancipação social é, assim, toda a acção que visa desnaturalizar a opressão (mostrar que ela, além de injusta, não é nem necessária nem irreversível) e concebê-la com as proporções em que pode ser combatida com os recursos à mão. A douta ignorância, a ecologia de saberes e a aposta são as formas de pensar que estão presentes nessa acção. E, de facto, da existência delas só temos prova no contexto dessa acção.

Quais as instituições da douta ignorância, da ecologia de saberes e da aposta? Da análise precedente, torna-se evidente que não têm instituições específicas onde possam ser exercitadas independentemente das práticas sociais que as mobilizam. Em vez de instituições, há contextos doutamente ignorantes, gnoseo-ecológicos e apostadores. Isto não significa que as instituições - universidades, centros de investigação - que foram moldadas pelo 
pensamento ortopédico e pela razão indolente estejam condenadas a ser reféns destes. Também elas são práticas sociais e nelas circulam - nas salas de aulas, nos corredores, nos bares, na extensão universitária, nas associações académicas - muitos saberes e práticas, incertezas e preocupações, culturas não oficiais, lutas por sobrevivência e libertação que não são reconhecidos pelos objectos purificados da educação certificada do curriculum formal. Uma vez relativizado este pelo procedimento da filosofia à venda, abrem-se campos de interacção onde a douta ignorância, a ecologia de saberes e a aposta podem ser exercitadas. Admito mesmo que, sobretudo nesta fase de transição, seja possível criar contextos híbridos onde intervêm as instituições do pensamento ortopédico e da razão indolente que logram distanciar-se relativamente deles e instituições e práticas de saber e agir que o pensamento ortopédico e a razão indolente consideraram ignorantes ou produziram como ausentes. ${ }^{19}$ Retiradas do seu refúgio indolente onde só respondem às perguntas que elas próprias formulam, as teorias e disciplinas podem dar um contributo útil na construção de um senso comum emancipatório.

Por último, quais as forças políticas adequadas à promoção da aposta em articulação com a douta ignorância e a ecologia de saberes? Certamente muito distintas das que têm promovido concepções ortopédicas e indolentes da emancipação social. Serão certamente organizações doutamente ignorantes, politicamente ecológicas e decididamente apostadoras nas potencialidades emancipatórias do quotidiano enquanto actio in proximis. Por agora, não é possível defini-las até porque a sua definição há-de começar por um processo correspondente à filosofia à venda, um processo já em curso, ainda que de modo incipiente. ${ }^{20}$ Captá-las constitui, pois, um exercício da sociologia das emergências.

\section{Referências bibliográficas}

André, João Maria (1997), Sentido, simbolismo e interpretação no discurso filosófico de Nicolau de Cusa. Lisboa: Fundação Calouste Gulbenkian/ JNICT.

André, João Maria (2001), "A actualidade do pensamento de Nicolau de Cusa: 'A douta ignorância' e o seu significado hermenêutico, ético e estético”, Revista Filosófica de Coimbra, 20, 313-332.

Doyle, John P. (2001), The Conimbricenses. Some Questions on Signs. Milwaukee: Marquette University Press.

${ }_{19}$ A proposta da universidade popular dos movimentos sociais, referida acima, é um desses contextos híbridos.

${ }^{20}$ É assim que concebo o processo do Fórum Social Mundial. Ver Santos, 2005. 
Fukuyama, Francis (1992), The End of History and the Last Man. London: Penguin Books.

Goldmann, Lucien (1966), Sciences bumaines et philosophie. Suivi de structuralisme génétique et création littéraire. Paris: Gonthier.

Goldmann, Lucien (1970), Structures mentales et création culturelle. Paris: 10/18, Union Générale d'Editions.

Habermas, Jurgen (1990), Die Moderne, ein unvollendetes Projekt: philosophisch-politische Aufsätze. Leipzig: Reclam.

Holloway, John (2002), Change the World without Taking the Power: The Meaning of Revolution Today. London: Pluto Press.

Isasi-Díaz, Ada Maria (2003), "Lo cotidiano, elemento intrínseco de la realidad", in Raul Fournet-Betancourt (org.), Resistencia y solidariedad. Globalización capitalista y liberación. Madrid: Editorial Trotta, 365-385.

Luciano de Samósata (1905), The Works of Luciano of Samosata. Oxford: Clarendon Press, vol.1.

Miller, Clyde Lee (2002), Reading Cusanus. Metaphor and Dialectic in a Conjectural Universe. Washigton, D.C.: The Catholic University of America Press.

Nicolau de Cusa (2003), A douta ignorância. Lisboa: Fundação Calouste Gulbenkian (trad. João Maria André).

Ortega y Gasset, José (1987), El tema de nuestro tiempo. Madrid: Alianza Editorial.

Pascal, Blaise (1988), Pensamentos. Mem Martins: Europa-América.

PNUD (2005), Relatório de desenvolvimento humano. Cooperação internacional numa encruzilhada: ajuda, comércio e segurança num mundo desigual (http://hdr.undp.org/ en/media/hdr05_po_complete.pdf).

Rancière, Jacques (1987), Le maître ignorant. Paris: Fayard.

Santos, Boaventura de Sousa (1987), Um discurso sobre as ciências. Porto: Edições Afrontamento.

Santos, Boaventura de Sousa (1995), Toward a New Common Sense: Law, Science and Politics in the Paradigmatic Transition. London: Routledge.

Santos, Boaventura de Sousa (2000), A crítica da razão indolente. Contra o desperdício da experiência, para um novo senso comum. Porto: Edições Afrontamento.

Santos, Boaventura de Sousa (org.) (2001), Globalização: Fatalidade ou utopia? Porto: Edições Afrontamento, 31-110.

Santos, Boaventura de Sousa (org.) (2003), Conhecimento prudente para uma vida decente: "Um discurso sobre as ciências" revisitado. Porto: Edições Afrontamento.

Santos, Boaventura de Sousa; Meneses, Maria Paula G.; Nunes, João Arriscado (2004), "Introdução: Para ampliar o cânone da ciência: a diversidade epistemológica do mundo”, in B. S. Santos (org.), Semear outras soluções: Os caminhos da biodiversidade e dos conhecimentos rivais. Porto: Edições Afrontamento, 19-101.

Santos, Boaventura de Sousa (2005), Fórum Social Mundial: Manual de uso. Porto: Edições Afrontamento. 
Santos, Boaventura de Sousa (2006), A gramática do tempo: Para uma nova cultura política. Porto: Edições Afrontamento.

Santos, Boaventura de Sousa (2007), "Para além do pensamento abissal: Das linhas globais a uma ecologia de saberes”, Revista Crítica de Ciências Sociais, 78, 3-46.

Santos, Boaventura de Sousa (2008a), "The World Social Forum and the Global Left", Politics and Society, 36(2).

Santos, Boaventura de Sousa (2008b), "A esquerda no século XXI: As lições do Fórum Social Mundial”, Oficina do CES, 298.

Santos, Boaventura de Sousa (no prelo), "If God were a Human Rights Activist: Human Rights and the Challenge of Political Theologies", Law Social Justice and Global Development. Colectânea de Homenagem a Upendra Baxi.

Santos, Leonel Ribeiro dos (2002), “A sabedoria do Idiota”, in João Maria André; Mariano Alvarez Gómez (org.), Coincidência dos opostos e concórdia. Caminhos do pensamento em Nicolau de Cusa. Coimbra: Faculdade de Letras, 67-98. 